\title{
The Digital Laocoön: Replication, Narrative and Authenticity
}

\author{
Stuart Jeffrey, Steve Love, Matthieu Poyade
}

\begin{abstract}
This paper examines what qualities and affordances of a digital object allow it to emerge as a new cultural object in its own right. Due to the relationship between authenticity and replication, this is particularly important for digital objects derived from real world objects, such as digital 'replicas'. Such objects are not an inauthentic or surrogate form of an 'authentic' object, but a new object with a complex relationship to the original and its own uses and affordances. The Digital Laocoön Immersive (VR exhibit), part of an AHRC funded project, was a response to the tragic fires at the Mackintosh Building of the Glasgow School of Art in 2014 and 2018. In this project a digital replica of a plaster cast of Laocoön, with a long history of use within the school, was chosen as the centre piece for the proposed immersive. As a consequence of both the immersive's design methodology and the lessons learnt in its production, the Laocoön proved to be an ideal subject through which to critically assess the question of the status of the replica. This paper will explore not only how the material infrastructure, form and content of digital representations have an impact on its broader set relationships, but how the concept of an extended object, its production processes, and the way that these are explicitly acknowledged (or not), operate on its relationship to the original.
\end{abstract}

Key words: Digital Replicas, Laocoön, Virtual Reality, Co-design, Extended Object

\section{Introduction}

This paper addresses the question of which qualities and affordances of a digital object allow it to emerge as a new cultural object in its own right. Due to the tangled relationship between authenticity and replication, this is a particularly important question for digital objects derived from real world objects, such as digital 'replicas'. Such objects should be differentiated from those that Geismar (2012) describes conceptually as 're-mediations of the authentic stuff', but not necessarily differentiated from the original material being represented, or, we will argue, from the modes of production and delivery of the digital object. Such objects are not an inauthentic or surrogate form of an 'authentic' object, but an entirely new object with a complex relationship to the original and possessing its own story, uses and affordances. This paper will explore not only how the material infrastructure, form and content of digital representations have an impact on this relationship, but also how the processes deployed in the production of the replica, and the way these processes are explicitly acknowledged (or not), operate on the relationship between the replica and the original. The paper will also discuss how multiple layers of rich contextual meaning, from the general to the personal, that implicitly adhere to many physical objects can be made explicit through digital technologies. In particular we will discuss the potential enhancement of an object's reception through the integration of layers of information and interpretation from sources that traditionally sit in entirely discrete domains. We will look at how this process simultaneously operates to differentiate the digital object from a simple representation of the original and binds the new representation with what is being represented. 
In this paper we will explore these issues by discussing them in the context of a recent case study undertaken by The Glasgow School of Art (GSA) and ISO Design funded by the Arts and Humanities Research Council (AHRC) via the 'Next Generation of Immersive Experiences' funding strand. This research into immersive representations of place, memory and performance was conducted through the production of a prototype interactive immersive (Virtual Reality (VR)) exhibit. The exhibit was initially intended for exhibition at a series of events celebrating the reopening of the GSA Mackintosh building (known as the 'Mack') after it had been damaged by fire in 2014. It has at its core a digital replica of the GSA's plaster cast version of the renowned classical statue of Laocoön and his sons, which was badly damaged in the 2014 fire.

The Mackintosh building, built 1897-1909, is considered by many to be the masterpiece of Glasgow's most globally significant architect, Charles Rennie Mackintosh (see Billcliffe 2017). Consequently, the building has an important role in the city's identity as an artistic and cultural centre, and the School of Art's identity in particular; for example, the GSA's School of Architecture is itself named after Mackintosh. The Laocoön sculptural group holds an important place in the history of Western art and had been used by generations of art school students as an important didactic tool. Tragically, the Mackintosh building suffered a second major fire during reconstruction (for a fuller description see Kincaid 2020: 30-2), just weeks before it was due to reopen, in 2018. In this fire the restored cast of the Laocoön was destroyed, resulting in this project's digital immersive becoming the most complete remaining representation of GSA's version of the Laocoön.

To understand the project's approach it is important to consider it in the light of replica and replication research, which in recent years has begun to significantly re-orientate the perception of curators in, for example, museums, art galleries and art schools, to the value and competing notions of authenticity that these replicas manifest. While this research encompasses all forms of material used in replication, the most problematic of these is the digital, the materiality of which is strikingly different both to the original and the replica's physical material(s). The Digital Laocoön project is a direct attempt to situate a new representation of the Laocoön within a long biographical chain beginning with the original sculpture. By engaging networks of people in co-design, embracing creative response, and by focussing on the specific affordances of the digital, the project endeavoured to create something that is intimately connected with, but is distinct from, a perceived original.

\section{Laocoön and his sons}

The Laocoön and his sons statue group, uncovered in 1506 in a Roman vineyard, once the site of the Baths of Trajan, and now in the Vatican Museum, has a very prominent place in art history. Indeed, one of the first visitors to its excavation was the great renaissance artist Michelangelo. ${ }^{1}$ The subject matter of the statue is itself ambiguous; there are multiple versions of the story of Laocoön and no definitive interpretation of what meaning was intended to be conveyed by the original sculptor(s). That Laocoön was a Trojan priest (of Poseidon, or possibly Apollo) and that he was punished by the Gods (for trying to expose the Trojan Horse, or possibly for having sex in the temple of Poseidon), by being killed by serpents along with both his sons (or survived while both, or one of his sons, died), is known, but what is meant to be learnt from this tale is less clear. Given that there are now various versions of this sculpture it is perhaps apposite that there appears to be no firmly graspable definitive original narrative acting as the genesis of the work. In fact, it is thought likely that the sculptors who created the statue uncovered in Rome were working somewhere between $27 \mathrm{BC}$ and 68 AD and were themselves creating a copy of a (now lost) bronze statue, possibly from Pergamon and dating to around $200 \mathrm{BC}^{2}$ Strictly speaking, then, the 'original' c. $2 \mathrm{~m}$ tall marble sculpture unearthed in the vineyard and bought by the Pope for display can itself be considered a replica (Figure 1). This ambiguity makes it an ideal starting point for what is a long and complex history of replication, copying, intermateriality and the restoration and additions that have occurred throughout its long biography.

Turning to the GSA's plaster cast version, Stevens $(2019: 24,25)$ points out that the nineteenth century fashion for buying casts of important works, especially for art schools, 
was seen as a process of democratization through granting access to replicas that gave an 'impression' of the original, i.e. they were at that time seen solely as a copy of an authentic original. Stevens also notes that the GSA Laocoön used in this project has itself elements of uncertainty. An 1849 GSA inventory details the 400 Franc cost (c. $£ 4000$ today) of a Laocoön Group cast from Jaquet, the well-known Paris formatori (Stevens 2019). This cast, which included Laocoön's sons, was brought to Glasgow by the well-known Victorian sculptor Baron Marochetti. However, it appears unlikely that this is in fact the version conserved after the 2014 fire, as that version consists solely of the central figure of the group (i.e. Laocoön himself). In fact, multiple versions of the group appear to have been purchased and there is another GSA inventory entry from 1900, which refers to a cast of the central figure only, this one purchased from Brucciani \& Co. (a company taken over by the Victoria and Albert Museum (V\&A) in 1922). The GSA continued to purchase various casts from Brucciani well into the twentieth century (Stevens 2019), but it is likely that it is the cast referred to in the 1900 catalogue that is the one replicated by the Digital Laocoön project.

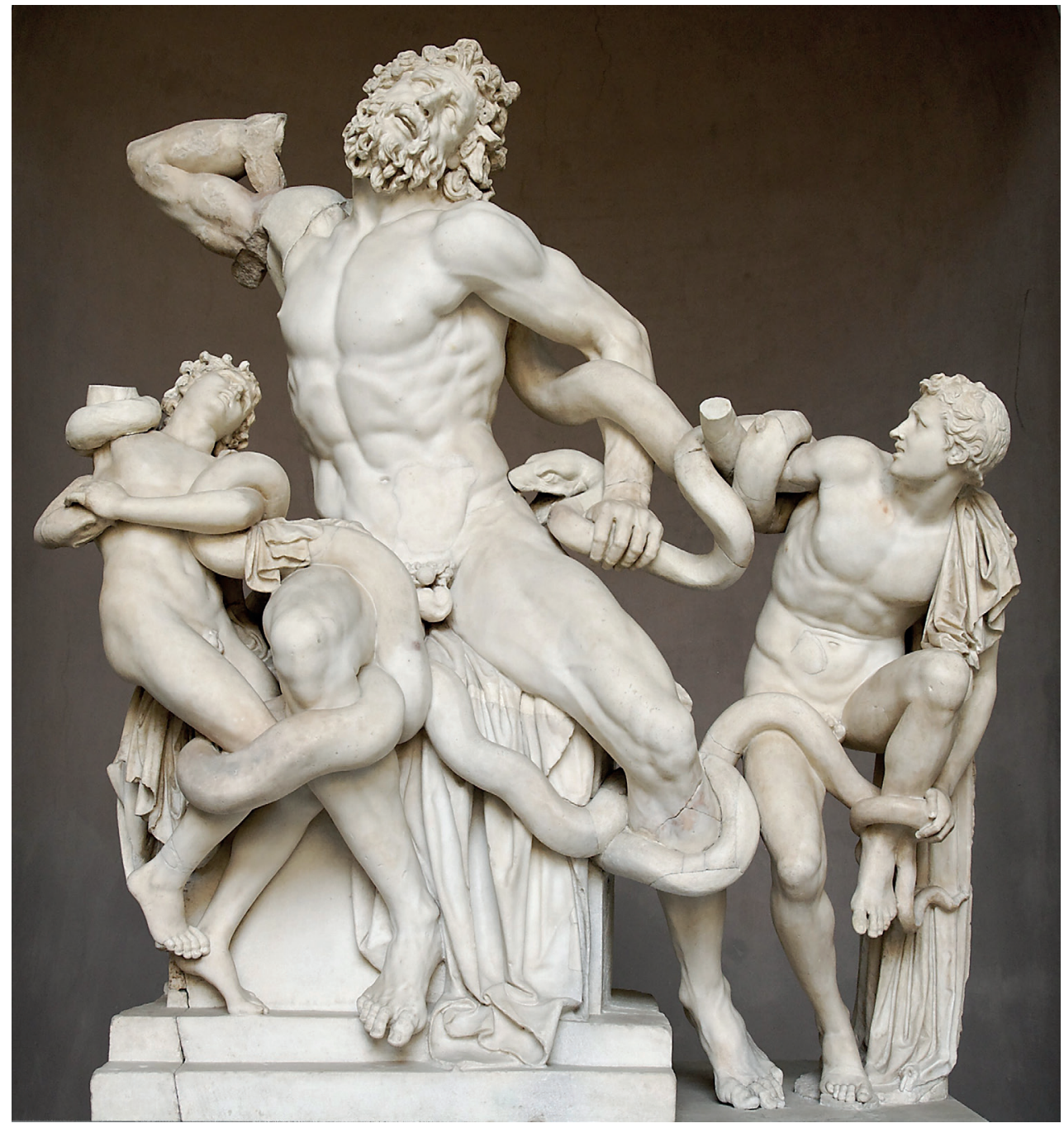

Figure 1. Laocoön and his sons (the Laocoön Group). Marble copy of a Hellenistic original from c. 200 BC. Found in the Baths of Trajan near Rome in 1506, currently in the Museo Pio-Clementino, The Vatican. Photographer: Marie-Lan Nguyen (2009), Public Domain (Wikimedia Commons). 
The story of the Laocoön group, with its multiple manifestations in multiple materials over millennia, must also be considered in light of the relatively recent re-thinking of the value and significance of replicas (Fyfe 2004), especially plaster casts. In their 2016 paper 'The Thing about Replicas: Why Historic Replicas Matter', Foster and Curtis lay out in detail the complex arrangements for the production, display, exchange and loaning of plaster casts (primarily of classical sculpture, but also of other display worthy antiquities) from the early nineteenth century onwards, encompassing private collections, museums, art galleries and, as described by Stevens above, art schools. It is now broadly accepted that the material form, artistry and often complex biographies of these casts allow new forms of authenticity and new values to emerge, challenging the plaster cast's role as a simple re-mediation of the original.

This re-evaluation of replicas now extends beyond plaster casts and encompasses other materials. Most notably, Foster and Jones (2019, 2020b) discuss the biography and multiple values associated with a 1970s concrete replica of an early mediaeval high cross (St John's) on the island of lona off the west coast of Scotland. What they describe is a rich and complex network of relationships around the replica cross, encompassing technical, artistic, spiritual and community values, which makes abundantly clear the multiple means by which a replica generates its own value and authenticity whilst remaining part of the extended biography of the original.

The argument that we should acknowledge the value of researching and actively managing physical replicas as artefacts in their own right is now beginning to be codified into management documents, such as Foster and Jones (2020a) and the V\&A's Reproduction of Art and Cultural Heritage $\left(\mathrm{ReACH}^{3}\right)$ Declaration (2017). Although the issues that digital replicas catalyse are similar in many ways to the questions engendered by physical replicas, the peculiarities of digital material add some further complexities (and opportunities) that do not adhere to the purely physical. This is particularly true with regards to the concepts of aura and authenticity and how they relate to a specifically digital replica (see Bolter et al. 2006; Cameron 2007; Jeffrey 2015, 2018; Di Giuseppantonio Di Franco et al. 2018 and Lowe et al. 2020). The Digital Laocoön project has implications both for technical methodological development and the less tangible aspects of how the digital replica is valued and considered authentic and auratic.

\section{Design Approach for the Digital Laocoön Immersive}

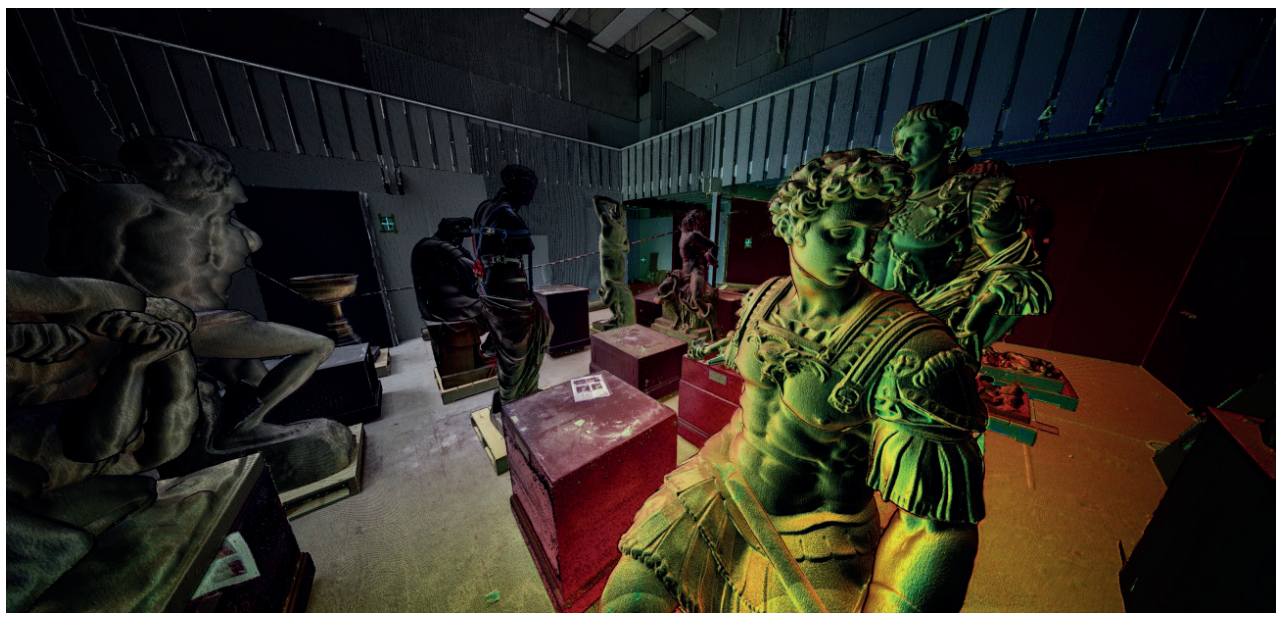

Figure 2. A very dense point cloud image showing the interior of the Mackintosh building with multiple plaster casts stored together in the aftermath of the 2014 Fire. In the centre background the Laocoön can be clearly seen. Image: Copyright GSA, SimVis 
Before discussing the design process for the Digital Laocoön Immersive, it is important to note that this project started from a very unusual position in that its fundamental dataset, the digital representation of the GSA's Laocoön plaster cast, was in fact created incidentally to a broader recording process of the Mack building. The base datasets for the Laocoön replica (which required extensive repair and re-modelling) was not the target of the original recording exercise. This recording, which was part of the School's immediate response to the 2014 fire, comprised a high-quality laser scan survey of the entire Mack building interior undertaken by SimVis and Historic Environment Scotland in collaboration (for a description of this process see Wilson et al. 2018). In the immediate aftermath of the fire, the Laocoön plaster cast had been moved from its original location into a studio in the Mack building that was crowded with a number of other casts (Figure 2). The laser scan survey was targeting the building's structure and not its contents. Therefore, the data collected for the Laocoön was incidental, and in terms of a technical approach, not necessarily what would have been collected, had the cast been the intended target.

As a result, the digital model of the Laocoön that was used in the immersive required extensive digital repair and reworking; this was the creative and skilled work of multiple digital modellers. From the outset the Digital Laocoön (Figure 3 ) was the product of not just the original artists in antiquity and the nineteenth century formatori, but of the technicians involved in the scanning and documentation process, and the modellers involved in its reworking. So even before engagement with the broader community of interest around the Mack (see below) and the creative designers, the digital object was already the product of an extensive network of practitioners.

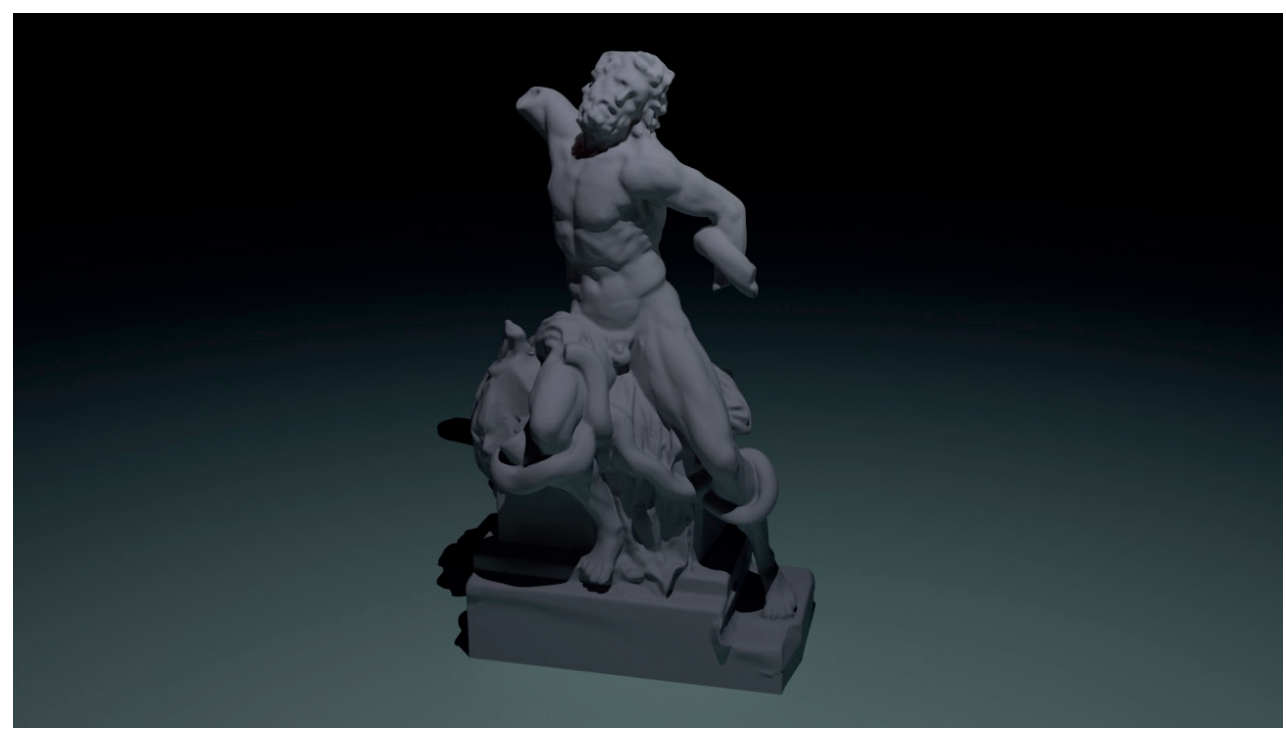

Figure 3. The extensively digitally repaired and reworked Laocoön extracted from the building survey laser scans for use in the Digital Laocoön project. Image: Copyright GSA, SimVis

From the outset the project's design methodology adopted a combination of two approaches for the production of the immersive itself: a user-centred design approach using co-design to gather and develop interactive digital content; and a rapid application development (RAD) model running in tandem with the co-design and co-production. RAD approaches to software development place a strong emphasis on an adaptive process as opposed to a rigorously phased development, for example, multiple prototypes are used instead of formal design specifications. RAD is considered most effective for developing software (in this case an immersive experience) that is focussed on user interface requirements (see Martin 1991). 
Co-design and co-production (see Cahn and Gray 2012) has begun to emerge as a significant route to enhancing the authenticity of a digital heritage object as well as the auratic quality of such forms. In addition to the aspects of production, such as the expenditure of resources noted by Latour and Lowe (2011) with regard to the aura of replicas, Jones (2009, 2010) has argued that the network of relationships around the production process directly influence both the quality of the replica and its reception. This has been further evidenced by community digital co-production exercises generating 3D digital content in the AHRC-funded ACCORD digital heritage community co-design and co-production project, discussed further below (Jeffrey et al. 2015; Jones et al. 2017).

As Stevens has pointed out (above), the plaster cast was a significant acquisition for the Art School and was already bound up in a network of major cultural figures in the city at that time, including Baron Marochetti (Stevens 2019). For the Digital Laocoön, however, the community was both place-based, i.e. focussed on the Mack building, and a 'community of interest' around the school and its recovery from the 2014 fire. For the Digital Laocoön, community co-design meant working together with multiple stakeholders and going through multiple iterations (RAD prototypes) of the immersive in response to feedback from three formally convened workshops and a host of formal and informal discussions. A wide range of interested groups were drawn in for the design workshops to discuss the development of the model, including GSA staff, ISO Design staff, GSA students, archivists, art historians, architects and what could loosely be called the 'Mackintosh community' of scholars focussing on Charles Rennie Mackintosh, which included representatives, for example, from the Hunterian Museum. ISO Design ${ }^{4}$ were a key project partner who drew on their extensive experience in creating digital content for heritage sites (such as the award-winning installations at the Titanic Experience in Belfast and the Stonehenge visitor centre in Wiltshire, England), with a focus on creative and affective components as well as technical user interface design.

Through the production workshops, the idea of the immersive simply being a representation of the plaster cast itself gave way to the notion that the immersive could integrate elements of other collections of data, each highlighting part of its biography. The experience of the immersive could, through a focus on the story of the cast, tell some of the broader story of recent events at the Mack. In many examples of digital documentation the 'cart' is all too often put before the 'horse', where the horse is a desire to inspire curiosity, inform and emotionally engage specific audiences and the cart is the technical process of digitizing something in the real world (Huggett 2004; Jeffrey 2015). While it was not possible to design the immersive before the digitization was undertaken for the reasons given above, the emergence of the notion that parallel datasets would be key to a meaningful output was a critical turn in the design process.

In terms of the affordances that digital objects can offer, one of the things that makes them different from representations in other materials, and what makes them unique 'things in themselves', is their ability to act as gateways or portals into richer datasets (Garstki 2016; Jeffrey 2018). The focus of development in this area has, understandably, been on the translation of Building Information Modelling (BIM) technology from a repository of technical, management datasets to include much broader types of data. However, to date, Historic BIM (or HBIM) has focussed almost entirely on integrating technical and conservation data into building models (see e.g. Antonopoulou and Bryan 2017). There is no technical reason why this is the case. A 3D model of a historic structure could retain within itself data (or references to data) that is archival, historical, social and creative. Similarly, a BIM approach does not have to focus on buildings; any digital object could in theory benefit from this approach. It is important to make the distinction here between associating data with elements of a model, essentially by a process of tagging/annotating the model (see e.g. Ponchio et al. 2020), and actually allowing a user agency in exploring a rich and complex underlying dataset through the model's user interface (UI). In the latter case the model becomes part 'information in its own right' and part 'interface into associated datasets'.

Jones, in her 2009 paper 'Experiencing Authenticity at Heritage Sites', states that 'tangible and intangible connections between heritage objects, people, and places are particularly important in the experience and negotiation of authenticity' (Jones 2009: 142); 
that this can also apply to conceptions of 'authenticity' for digital objects has been strongly argued elsewhere (Jeffrey 2018). What is clear is that such an object can self-document its own biography and, in turn, its position within the biography and relationship to an original object. This further enhances the digital object as an 'extended object', a replica that not only extends connections backwards to an original (or is an extension of that object), and its subsequent replicas and intermaterial instantiations, but also extends itself to incorporate, or reference, a broader field of associated data.

The notion of an extended object clearly alludes to assemblage theory defined by Deleuze and Guattari (1987) and discussed in a heritage context by McDonald (2009: 118). It emphasizes the fluid and contingent nature of the relationship between what is an historic original or a replica and the relationship of both of these concepts to external bodies. Importantly, it builds on this by attempting to explicitly reference relationships to external bodies and/or explicitly incorporate elements of these within itself. The story of the Laocoön group and its multiple instantiations is an excellent illustration of these complex relationships as they occur in the physical domain. Also, the Digital Laocoön, as described below, absorbing and referencing multiple external elements to transform itself into something distinct from the object that was its genesis, is a good example of an extended object. It must be acknowledged here that, unless the extended object is a 'living document' (i.e. one that is constantly updated, for example using Linked Data approaches), then the interconnectedness with the outside world and the elements it incorporates are at once ossified and partial, depending as they do on the perceptions of value and significance held by the creator community. Although unrealized in the Digital Laocoön project, the mobilization of dynamic extended creator communities, including non-expert and public contributors, was seen as a potentially fruitful future enhancement of the production process for digital replicas and their continued evolution through time.

\section{The Digital Laocoön Immersive}

The Digital Laocoön Immersive was designed in parallel to an Augmented Reality (AR) version of the cast meant to be used as a place-based version of the product in the physical presence of the restored Laocoön plaster cast. For obvious reasons this is no longer possible, although the AR version can still be triggered by a 3D print of the GSA Laocoön digital model (yet another version of the Laocoön in yet another material). The section below focusses on describing the full VR immersive and its content. The immersive was designed specifically for delivery via an HTC Vive head tracked (infrared) VR rig, which allows a user in a Vive headset almost complete freedom of movement within a closely defined physical (and virtual) space. Figures (Figs 4-8) illustrating scenes from the Digital Laocoön Immersive experience are included in the following sections; however, the best impression of the immersive, without actually using it, can be gained from a video giving a First Person point of view (PoV) walk through of the experience, it is available online: $h t t p s: / / y o u t u . b e / K i M-9 V i j V 88$

The immersive experience unfolds as a directed narrative. While the user can move around in space, and can look around a full 360 degrees, what they see and hear is, with few exceptions, controlled and time constrained. In effect the user enters a VR space and is taken on a journey, lasting five minutes or so, which presents curated content on the history of the sculpture, the history of the Mack, and the relationship between the two. Multiple channels are used to deliver information. The visual design paradigm was not fundamentally based on photo-realism; instead, a highly stylised and dynamic environment is presented to the user. This approach emerged from the co-design process and reflects a strong desire to affectively engage the audience intellectually with the story of the Laocoön cast and the Mack. There has been a long debate on realism in heritage visualizations (e.g. Gillings 2005), and in this instance much of the final design, described below (see also Figures 4-8) is powerful, engaging, and moving, despite, or perhaps because of, not attempting to represent space, lighting, or textures realistically. To support the narrative elements selected by the design community the experience is split into a series of scenes or vignettes, each representing a different phase of the history of the statue or plaster cast and each presenting design challenges in themselves, particularly in the transitions between vignettes. Each is described briefly below. 


\section{Opening Scene}

The user arrives (i.e. essentially 'materializes') in a dark space in front of a dramatically top-lit version of the Laocoön with a reflective, almost metallic texture (Figure 4). A narration starts, providing an art historical background to the story of the statue and its early versions, starting with a version including Laocoön's sons. At this point the user can move around the statue (using a head tracking device). The only focus is the statue and the narration, and it

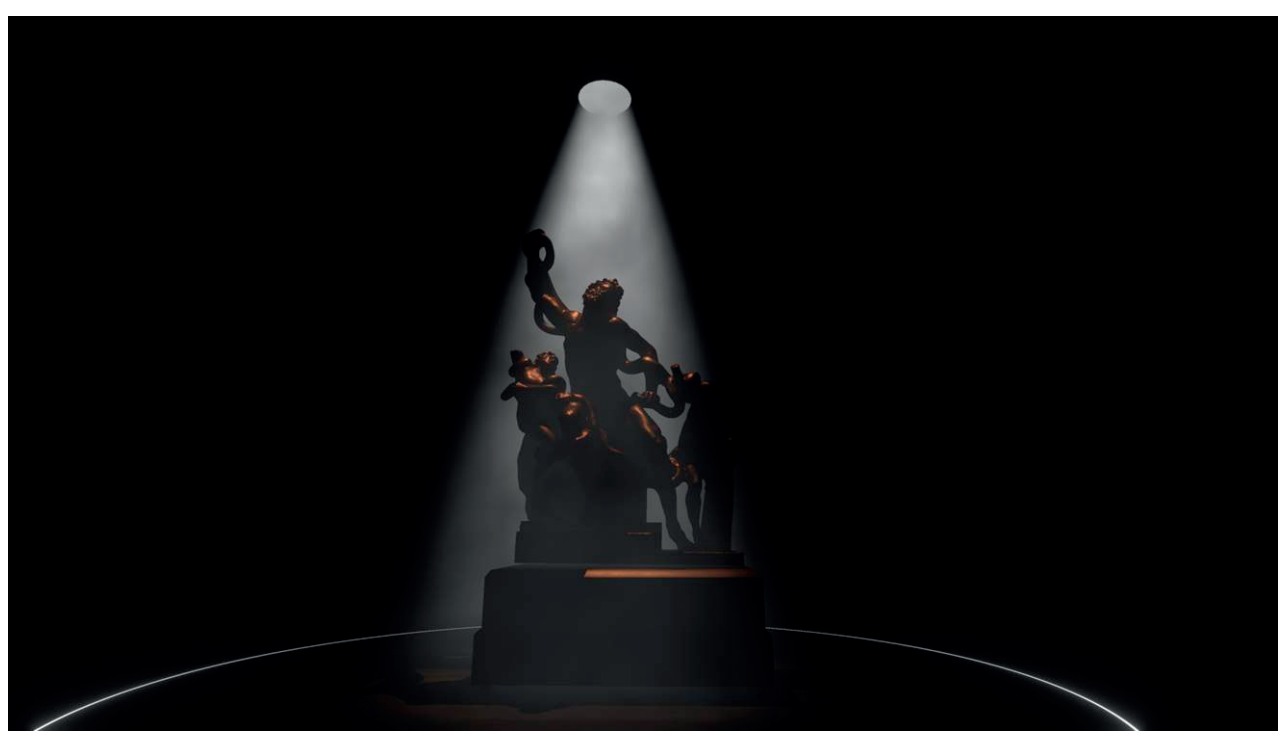

Figure 4. The highly abstracted and atmospheric opening scene of the immersive. Image: Copyright GSA, SimVis.

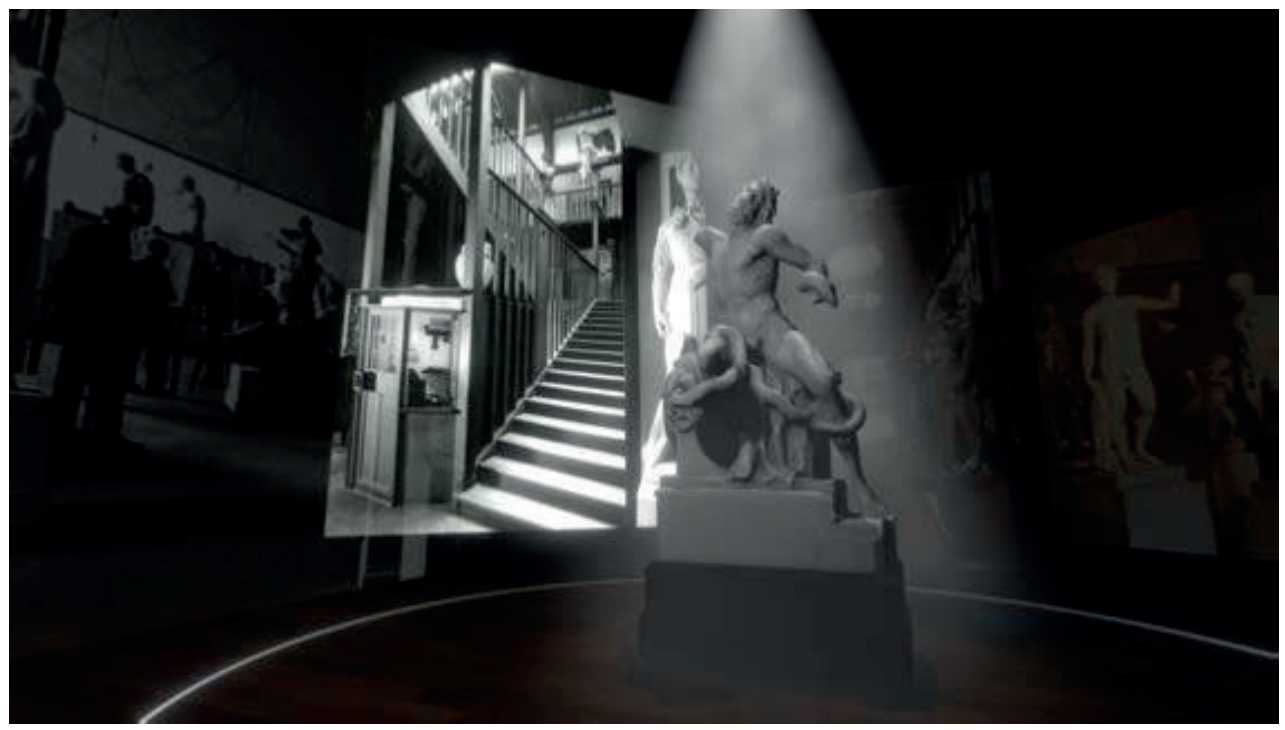

Figure 5. The Laocoön in context, in the building with multiple historical images of casts in use, each utilizing and reflecting the perspective of the immersive space. Image: Copyright GSA, SimVis. 
is assumed that the user would only walk round the statue, before the scene fades to dark.

\section{Plaster Version}

The next scene in which the user materializes is brighter, but monochrome. There is an indicative (semi-transparent) 3D model representing the central staircase in the Mack. The Laocoön model is textured in light colours representing either marble, or as the narration makes clear, plaster. Laocoön's sons are no longer included. This is the version most familiar to the GSA, Laocoön only, without his sons. The narration now describes the history of the plaster cast collection in the Mack and a series of historical images fills the scene. These are highlighted by the user's gaze triggering a brighter lighting condition (i.e. the head tracking device detects the user looking in a particular direction and triggers an event associated with an object; looking away returns the object to its previous state). The monochrome nature of this scene allows for the integration of the 3D model and the historical (but obviously 2D) images of the casts in use in the Mack to work well together without jarring colours. This scene is doubly effective as the careful positioning of images, many with extended perspectives, results in an enhanced sense of immersion. At times it is hard to detect what is model space and what is historical image (Figure 5).

\section{First Fire, 2014}

As a consequence of the plaster cast vignette (above) being so effective in terms of immersion and in instilling in the user a sense of the long use and long history of the Laocoön cast, this scene, depicting the 2014 fire, comes as a shock. There is a transition interaction via gaze activation to no interaction at all. This change actually enhances the sense that what is about to happen is beyond the user's control. In a darkened space, the Laocoön seems to glow red, as the narrator describes the events of 23 May 2014, and the cast appears to degrade and dissipate before the user's eyes. Eventually the Laocoön fragments into glowing sparks and embers and floats upwards into the dark, leaving behind the smoke darkened cast. While this is not a literal representation of the damage incurred, it is a powerful evocation of the event itself. The darkened surface is strongly redolent of the passage of time and the marks of real events, such as patination, which acts as an indicator of the object's history or 'pastness', as Holtorf (2013) terms it.

\section{Repair and Reconstruction}

The next scene starts with a fade into a bright, almost clinical, space. The damaged Laocoön is now textured with the charred and blackened surface left after the fire (Figure 6). This texture is one of the few photo-real elements of the immersive, being derived from images of the Laocoön under restoration. This change in design from representative/indicative to photo-real, as well as the change in environment - a studio space in the Mack - strongly signals that a new episode in the biography of the cast is underway. This is the technical/scientific process of restoration. The user's gaze is again allowed to trigger richer content as the user moves around the statue under conservation. This content includes still images and videos of the technical processes, such as endoscopy and the injection of consolidants. The videos pop into being in the 3D space and comprise interviews with key actors in the restoration process, such as noted conservator Graciela Ainsworth. Ainsworth gives a detailed and informative description of some of the technical processes, and art historian Thea Stevens describes the changes in the material nature of the Laocoön through the fire and the later restoration process. This is an emotional narrative that draws the user into a deepening engagement with the Laocoön through sharing Stevens' insight. After a period of user directed exploration the narrative arc of the immersive resumes, indicated by the restarting of the narration.

\section{Second Fire, 2018}

The representation of the second fire to strike the Mackintosh building (15 June 2018) is much more threatening than the 2014 fire scene described above. The flames and effects, including 
audio, are more realistic and more dramatic than the previous fire scene (Figure 7). This fire was a much more destructive event than in 2014, effectively destroying the interior of the building; these elements of the building itself are represented in this scene. The conclusion of this sequence is a cloud of fiery embers that swirl around the user before dissolving to nothing. We believe this effect directly inspires a sense of loss and creates a space for the user to consider the previous scenes before moving to the next. It was this scene that elicited the greatest emotional response during demonstrations as part of the co-design process, including on more than one occasion, tears.

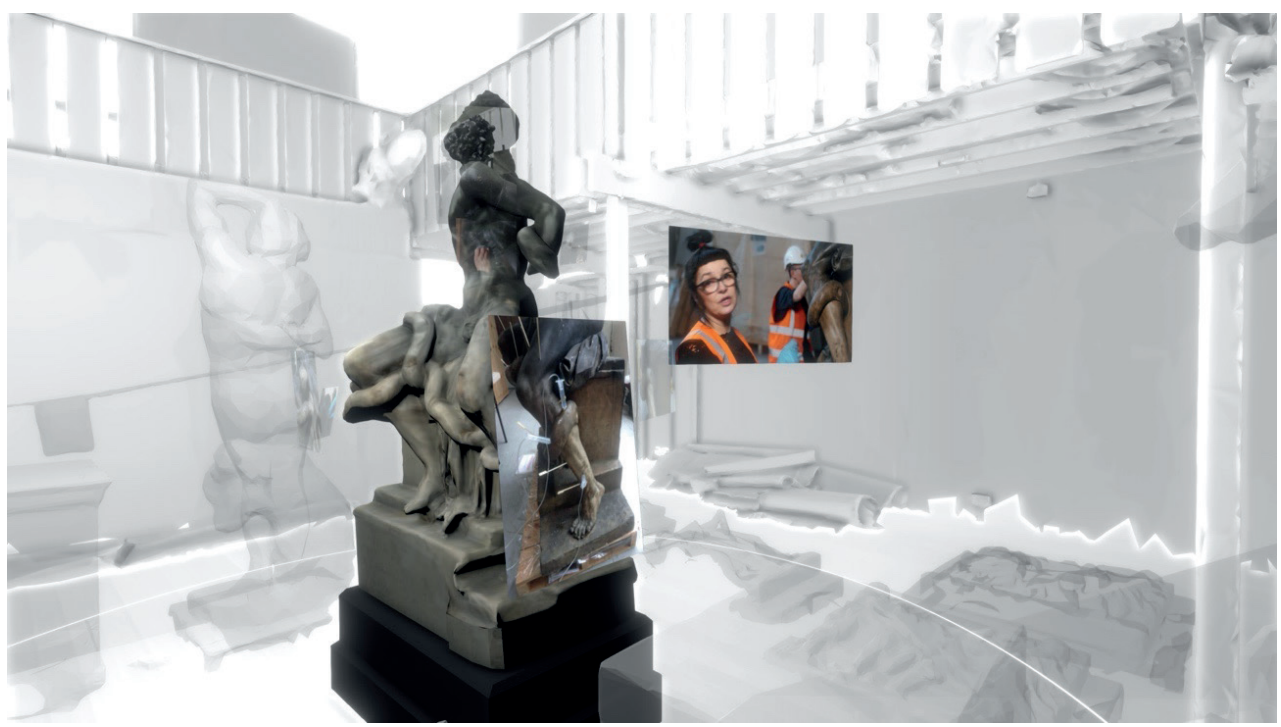

Figure 6. An abstract version of the Mack Building studio with multiple gaze activated videos and still images focussing on the conservation process. Image: Copyright GSA, SimVis

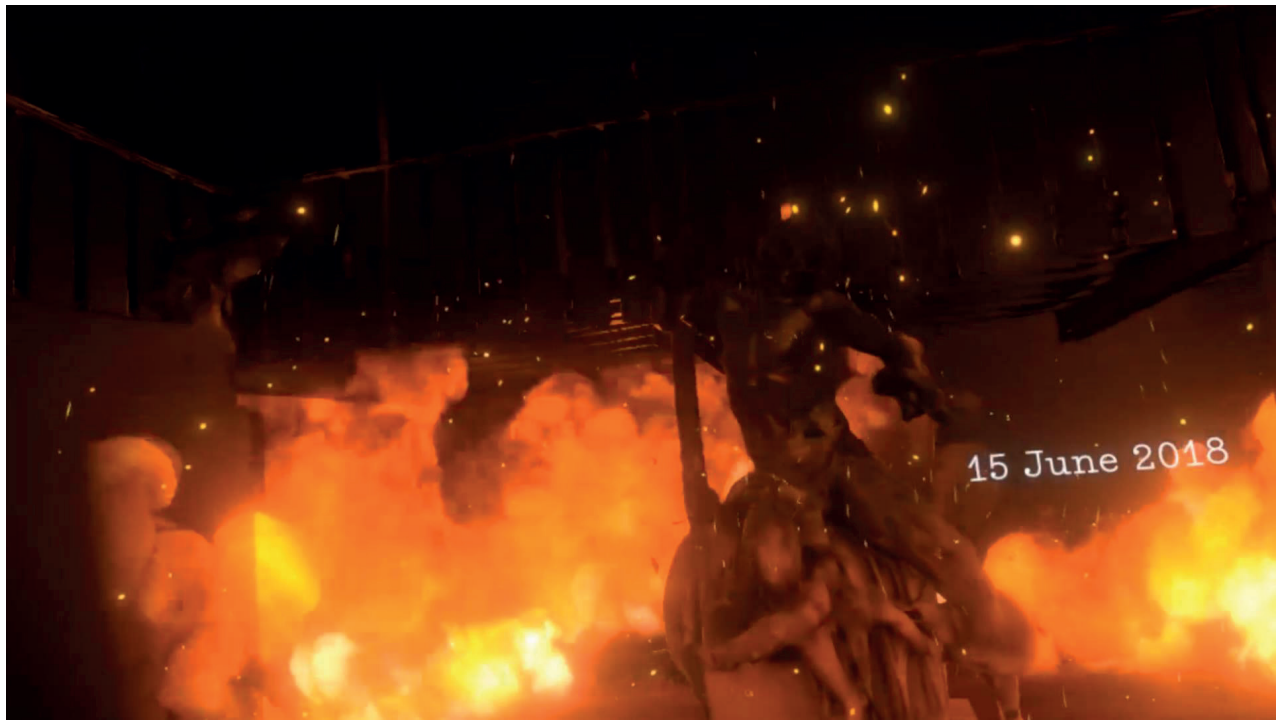

Figure 7. The initial scenes representing the catastrophic 2018 fire. Image: Copyright GSA, SimVis 


\section{The Digital Laocoön}

From the point of view of the debates around replicas and replication, this is perhaps the most interesting scene in the immersive's narrative. The physical cast in its restored version is now gone, having been destroyed in the second fire, but we still see the statue. This is the digital model, no longer just a representation of the lost plaster cast (the 'authentic stuff'), but as a meaningful object in its own right. The affordances of the digital, including this digital immersive, are heavily referenced in this scene: point clouds and infinite reproducibility, 3D printing, the possibilities the digital form affords with regards to texturing, scaling and reshaping (for a fuller discussion of the use of scale in the context of immersives see Jeffrey 2021).

The aesthetic appeal of point clouds themselves in heritage contexts has previously been noted and exploited (see Chapman et al. 2018), including specifically in the context of the Mackintosh building scans from 2014 (Jeffrey 2015). Here the use of the point cloud, a nebulous collection of points derived from the original laser scan, also highlights the immaterial nature of the digital model in comparison to its real world counterpart. The very final shot of the whole experience is a striking vision of multiple digital copies of the Laocoön together (Figure 8). This visually references the reproducibility of the digital, but it also begins to hint at the extended family of Laocoöns that exist in the world in multiple places and in multiple materials and forms.

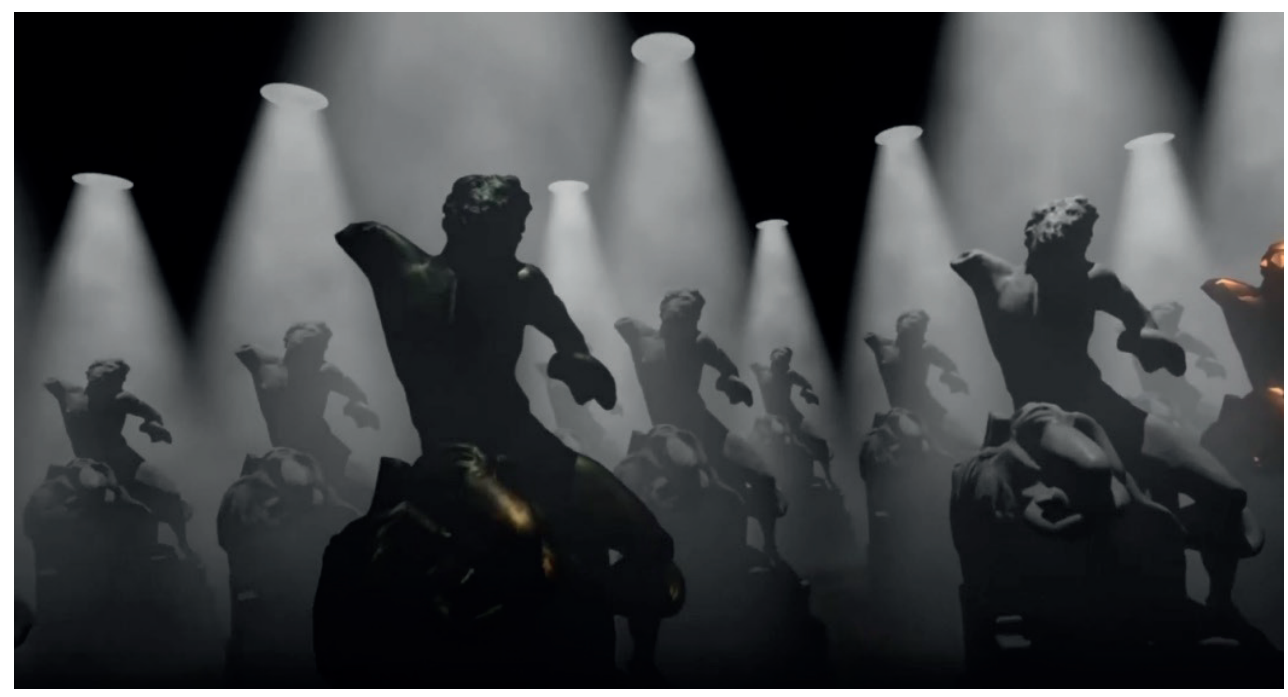

Figure 8. Multiple digital copies of the Laocoön shown together. Image: Copyright GSA, SimVis

From the perspective of digital objects being seen as re-mediations of the authentic stuff, this final scene brings us full circle, demonstrating that the digital object may extend from an original, but is a thing in itself, with its own affordances and its own network of relationships. In this instance too, it is also sadly the nearest we can approach the 'authentic stuff' in the chain of proximity between originals and (multiple) replicas (Jeffrey 2015: 147), given that the original (replica) is now destroyed. While the design of the immersive is clearly intended to create an extended object with links to its historic original, external sources, and its own affordances, there remain some design elements that would have bolstered this process. For example, narration breaks from a free exploration interface design by requiring that the user's attention is directed to (or directed by) the spoken narrative. This has the effect of transforming the interaction from an un-time-bounded, curiosity driven exploration to a directed and constructed narrative 'experience', which is necessarily time-bounded. The parallel development of an AR version, which is without narrative, offers this unbounded alternative, but there is no equivalent immersive version of this. In the case of the Digital 
Laocoön specifically, this is due to the envisaging of the immersive as an installation, rather than something that can be independently revisited, and the desire to ensure that the user actually gets exposed to all the highly designed aspects of the experience. So the narrative guides the user on a journey beginning with the 1506 Laocoön, to the Laocoön cast in-situ in the 'Mack', its long history of use by the Art School community, its damage in 2014, its restoration, and its ultimate destruction in 2018, finally followed by its digital instantiation through this project.

Choosing an installation as a mode of delivery raises issues of creating a sense of immersion and engagement while moving between the real world and the virtual reality, resulting in abrupt and dissonant changes in the user's perceived experience. For example, the experience begins in a quiet, darkened space with a top-lit version of the statue (Figure 4 above); it is stark and without context and the area around seems infinite. It is a powerful and appealing representation of an imagined world, as it was designed to be. However, we should consider the effect of moving into this environment from a real-world environment that might be brightly lit, busy and noisy. By paying attention to the transition from the real world to the virtual, we would argue that we can facilitate and enhance this transition phase (these issues were also recently noted in a NESTA Policy discussion paper ${ }^{5}$ ). Through creating a physical environment that starts to reference or echo the virtual environment, for example in terms of lighting, the experience of transitioning to the virtual may become quicker and less uncomfortable. How quickly the user feels comfortable and 'immersed' in an experience matters particularly when the experience is time-bound, as with the Digital Laocoön. Finally, while the immersive's soundscape is dominated by the narration or by recorded interviews, there are some sound effects, notably in the two fire scenes. This project did not allow for the full development of spatialized audio, which can both enhance a sense of immersion and also act as a further information channel, directing the user's attention as well as informing them of context directly. With spatialized sound (via stereo or higher factor sound systems) the 3D position of a sound in space can be represented and the user experiences this sound from that location even as the position of their head moves within that space. This approach has become increasingly common in video games that use head tracking technology. SimVis has also developed immersives for heritage sites that deploy the technology, for example at Fingal's Cave in Scotland (this also included real-time acoustic response, see Noble 2019). This is not simply a question of technical development. Levels of interaction and deepening a sense of immersion all impact the user's engagement with the digital object. These are the affordances that distinguish the extended digital object from its historic original, or from a reconstruction of the original, imbuing it with its own identity and authenticity.

\section{The extended object}

Any formal evaluation of the Digital Laocoön project should be considered in light of the fact that the second fire in the Mack occurred while the project was underway, and the presentation events for which it was originally conceived, i.e. events around the reopening of the refurbished Mack, did not take place. This deprived the project of the opportunity for a full evaluation using protocols for evaluating immersives (including for emotional engagement), such as those developed by Pujol and Champion (2012) or the EU EMOTIVE project. ${ }^{6}$ Despite this, through the example of the Digital Laocoön's story, we have highlighted broader questions around engagement and aura, and what replication means for this quality of an object, whatever its material. Substantively, discussions on aura and authenticity revolve around the key issues of intentionality, expertise and the modes of production (see Latour and Lowe 2011; Jones and Yarrow 2013).

In terms of modes of production, the co-design methodology adopted by this project to some extent followed a model echoing the ACCORD project as described by Jeffrey et al. (2015) and Jones et al. (2017), and reflects this project's results regarding authenticity and the production of value in digital replicas when co-design is deployed. The ACCORD project engaged ten local community groups across Scotland in the co-production of digital heritage objects. Heritage sites were selected by the communities and recording techniques such as photogrammetry were deployed to create digital objects. While the project had 
multiple objectives, a key aspect of the work was the examination, through the use of rapid ethnographic intervention (Pink and Morgan 2013), of how co-production facilitates the creation of new forms of authenticity through the migration of the aura from an original (and indeed the production of significance around previously insignificant aspects of heritage, see Jeffrey et al 2020). In a similar way, the inclusion of the wider community of interest around Mackintosh has been instrumental in transforming the damaged Laocoön plaster cast and its digital replica, essentially a single element within the Mack Building, into something emblematic of the whole, such that it came to stand for a broader narrative of destruction, reconstruction and loss. The process of uncovering the history of the cast at the GSA with this community made explicit how the digital replica is related to, but separate from the cast and also the story of the original Laocoön group on which it was modelled. The Mack's fires are episodes in the biography of the cast, not of the historic Laocoön; however, the digital replica (through the immersive) extends their biographies and creates something new that draws on, and materializes, the stories of both.

The Digital Laocoön project, then, has been successful in three key areas: the contribution of expert communities involved in co-production in combination with a Rapid Application Development paradigm, the richness of content folded into the experience along with its striking visual design, and finally as a demonstration of how an extended object has a life beyond its original. The intention, the modes of production and the specific affordances of the digital replica all contribute to its emergence as a distinct thing in the world.

In the course of the project it became clear that there are other forms of community that an extended object might reference. Most strikingly, there is the larger global community, or family, of Laocoön replicas. Very little effort is needed to find the location and intricate histories of a huge number of other Laocoön replicas. The significance of the sculpture group and the prestige associated with a high-quality replica has meant that these are distributed around the world in museums, galleries and private collections. This family of replicas comprises many other historic plaster casts from the same and other makers discussed above, but the community has also more recently come to include a large number of digital replicas, mostly generated from the plaster casts themselves (for example see just one online 3D hosting site, Sketchfab, ${ }^{7}$ which has nearly 20 digital versions available online). We should also consider the host of other creative responses directly inspired by the original work of art, such as Joshua Hammond's skeletal version created for an exhibition called Death by Natural Causes at the Houston Museum of Natural Science. ${ }^{8}$ As if to further demonstrate the interconnectedness and complexity of the Laocoön family, the Hammond version is itself inspired by an earlier version of the Laocoön group in skeletal form created by Josef Hyrtil in 1924, but destroyed by bombing in World War II (a photograph remains in the Wellcome Collection ${ }^{9}$ ).

There is, then, external to the GSA, a global and historic community of Laocoöns, which taken together can tell a much richer story about the significance of the Laocoön legend(s), the significance of the artworks it has inspired, and the types of material used to create them. An exploration of this network would span geography, time and multiple other pertinent factors such as trade (Foster and Curtis 2016 discuss this in depth for historic plaster casts), replication culture, artistic fashion and no doubt much more. The existence of this network of replicas is important in understanding the significance of any single instance of an object, the first version or the last. It is only the digital that meaningfully offers a way to integrate connected and interdependent elements of the Laocoön story, of which the Laocoön at the GSA and the story of the Mack building is itself a part.

The reconceptualization of digital records (or replicas) from static, isolated documents to the conduit (or access point) for much broader contextual datasets through the creation of an extended object is discussed above. While the Digital Laocoön clearly operates in this way with regards to the data drawn from the GSA's own collection, i.e. it is an extended object in itself, it remains both an isolated and hermetic digital object and one with little user agency. An obvious, and very exciting, enhancement to the Digital Laocoön would be to further extend it, to make connections, digitally, with the other members of the family that already exist in the world, allowing a user to follow their curiosity to other digital instances, for example other sculptures and replicas, which in turn act as portals to other contextual datasets. Situating the GSA's digital replica within the wider family of Laocoöns could, we believe, have greater 
impact than simply serving to enhance the broader contextualization of the digital replica and highlight wider, particularly historical, aspects of the replication process. We believe that extending further the external links referenced within the extended object to include this wider context, as well as the community involved in its production, would further advance the role of co-design/co-production in generating new forms of object, each ultimately manifesting their own form of authenticity.

Received: 13 July 2020 Finally accepted: 1 June 2021

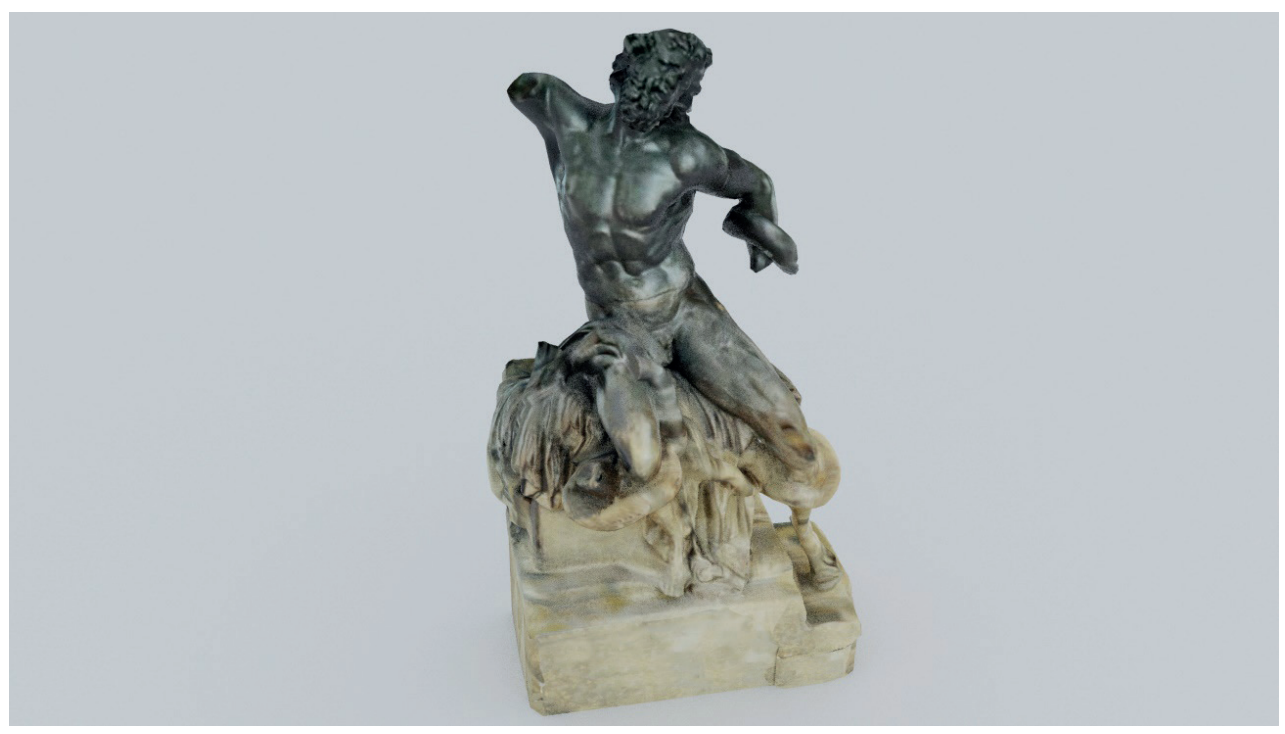

Figure 9. The Mackintosh Laocoön with photorealistic textures, clearly showing the fire damage caused by the penultimate chapter in the object's biography. Image: Copyright GSA, SimVis

\section{Acknowledgments}

The authors would like to express their gratitude to the Arts and Humanities Research Council for funding this research (Grant No. AH/R010196/1), our partners at ISO Design, Mark Breslin, Lauren Glasgow and Damien Smith for their outstanding expertise, generous engagement and management of the project. Thanks to Jordan Trench at SimVis for his excellent early development work. We would also like to thank colleagues at the GSA, including Dr Thea Stevens and Dr Robyn Calvert, as well as the many colleagues from within and without the GSA that participated in the development workshops and the creation of the content for inclusion in the immersive.

\section{Notes}

1 Encyclopaedia of Art, http://www.visual-arts-cork.com/sculpture/laocoon.htm, accessed July 2020.

2 See Bernard Frischer, "Digital Sculpture Project: An Annotated Chronology of the "Laocoon" Statue Group', The Digital Sculpture Project, 2009. http://www.digitalsculpture.org/laocoon/ chronology/index.html, accessed June 2021.

3 Victoria \& Albert Museum, 'Reproduction of Art and Cultural Heritage (ReACH)', 2017. https://vanda-production-assets.s3.amazonaws.com/2017/12/15/14/49/22/a743acd86522-48ce-8700-7b78e59c8bf2/ReACHDeclaration.pdf, accessed July 2020. 
https://isodesign.co.uk/, accessed July 2020.

5 Jenny Kidd and Eva Nieto McAvoy, 'Immersive Experiences in Museums, Galleries and Heritage Sites: A Review of Research Findings and Issues', Creative Industries Policy and Evidence Centre, NESTA 14 November 2019. https://pec.ac.uk/discussion-papers/ immersive-experiences-in-museums-galleries-and-heritage-sites-a-review-of-researchfindings-and-issues, accessed July 2020.

6 Maria Economou, Sara Perry, Hilary Young, Akrivi Katifori and Maria Roussou, 'D9.1 - Evaluation Framework and Guidelines', EMOTIVE: Storytelling for Cultural Heritage, 2017. https://emotiveproject.eu/wp-content/uploads/2018/11/EMOTIVE D9.1 Evaluation Framework Guidelines v1.0.pdf, accessed July 2020.

7 https://sketchfab.com/, accessed July 2020.

8 Jef Rouner, 'Behind the Bone Statues at Death by Natural Causes at the Museum of Natural Sciences', Houston Press 25 June 2018.https://www.houstonpress.com/arts/ laocoon-comes-alive-sort-of-at-the-houston-museum-of-natural-science-10587591. accessed July 2020.

$9 \quad$ Wellcome Library, Reference: 566107i.

\section{References}

Antonopoulou, S. and Bryan, P. (2017) BIM for Heritage - Developing a Historic Building Information Model, Swindon: Historic England.

Billcliffe, R. (2017) Charles Rennie Mackintosh and the Art of The Four, Frances Lincoln: London.

Bolter, J.D., Maclntyre, B., Gandy, M. and Schweitzer, P. (2006) 'New Media and the Permanent Crisis of Aura', Convergence, 12 (1) 21-39.

Cahn, E.S. and Gray, C. (2012) 'Co-Production from a Normative Perspective', in Victor Pestoff, Taco Brandsen and Bram Verschuere (eds) New Public Governance, the Third Sector and Co-Production, 129-44, Abingdon: Routledge.

Cameron, F. (2007) 'Beyond the Cult of the Replicant: Museums and Historical Digital Objects - Traditional Concerns, New Discourses', in Fiona Cameron and Sarah Kenderdine (eds) Theorizing Digital Heritage: A Critical Discourse, 49-76, Cambridge, Mass.: MIT Press.

Chapman, P., Mitchell, D., McGregor, C., Wilson, L. and Rawlinson, A. (eds) (2018) Art of the Point Cloud, Glasgow: Wild Harbour Books. ISBN 9781999718916.

Deleuze, G. and Guattari, F. (1987) A Thousand Plateaus, Minneapolis: University of Minnesota Press.

Di Giuseppantonio Di Franco, P., Galeazzi, F. and Vassallo, V. (eds) (2018) Authenticity and Cultural Heritage in the Age of 3D Digital Reproductions, Cambridge: McDonald Institute for Archaeological Research, University of Cambridge. DOI: 10.17863/CAM.27029.

Foster, S.M. and Curtis, N.G.W. (2016) 'The Thing about Replicas: Why Historic Replicas Matter', European Journal of Archaeology 19 (1) 122-48. DOI:10.1179/146195711 5Y.0000000011. 
Foster, S. and Jones, S. (2019) 'The Untold Heritage Value and Significance of Replicas', Conservation and Management of Archaeological Sites, 21 (1) 1-24. DOI: 10.1080/13505033.2019.1588008.

(2020a) New Futures for Replicas: Principles and Guidance for Museums and Heritage, Stirling: University of Stirling. https://replicas.stir.ac.uk/principles-andguidancel.

(2020b) My Life as a Replica, Oxford: Windgather Press. ISBN: 9781911188599.

Fyfe, G. (2004) 'Reproduction, Cultural Capital and Museums: Aspects of the Culture of Copies' Museum and Society, 2 (1) 47-67.

Garstki, K. (2016) 'Virtual Representation: The Production of 3D Digital Artefacts', Journal of Archaeological Theory and Method, 24 (3) 726-50.

Geismar, H. (2012) 'Museums + Digital=?', in Daniel Miller and Heather A. Horst (eds) Digital Anthropology, 266-87, London: Berg.

Gillings, M. (2005) 'The Real, the Virtually Real, and the Hyperreal: The Role of VR in Archaeology', in Sam Smiles and Stephanie Moser (eds) Envisioning the Past: Archaeology and the Image, 223-39, Oxford: Blackwell Publishing Ltd.

Holtorf, C. (2013) 'On Pastness: a Reconsideration of Materiality in Archaeological Object Authenticity', Anthropological Quarterly 86 (2) 427-43.

Huggett, J. (2004) 'Archaeology and the New Technological Fetishism', Archeologia e Calcolatori 15 81-92.

Jeffrey, S. (2015) 'Challenging Heritage Visualisation: Beauty, Aura and Democratisation', Open Archaeology 1 144-52.

(2018) 'Digital Heritage Objects, Authorship, Ownership and Engagement', in Paola Di Giuseppantonio Di Franco, Fabrizio Galeazzi and Valentina Vassallo (eds) Authenticity and Cultural Heritage in the Age of 3D Digital Reproductions, 49-46, Cambridge: McDonald Institute for Archaeological Research, University of Cambridge. ISBN 978-1-902937-85-4, DOI:10.17863/CAM.27037.

(2021) (Forthcoming) 'The Work of the Miniature in the Age of Digital Reproduction', in Andrew M. Jones, Paul Reilly, Ian Dawson and Louise Minkin, (eds) Diffracting Digital Images in Art, Archaeology and Cultural Heritage: Unfolding Pixels, Abingdon: Routledge.

Jeffrey, S., Hale, A., Jones, C., Jones, S. and Maxwell, M. (2015) 'The ACCORD Project: Archaeological Community Co-Production of Research Resources', in F. Giligny, F. Djindjian, L. Costa, P. Moscati and S. Robert (eds) Proceedings of the 42nd Annual Conference on Computer Applications and Quantitative Methods in Archaeology, CAA 2014, 1-7, Paris: CAA.

Jeffrey, S., Jones, S., Maxwell, M., Hale, A. and Jones, C. (2020) '3D Visualisation, Communities and the Production of Significance', International Journal of Heritage Studies, 26 (9) 885-900. ISSN 1352-7258 https://doi.org/10.1080/13527258.2020.1 731703. 
Jones, S. (2009) 'Experiencing Authenticity at Heritage Sites: Some Implications for Heritage Management and Conservation', Conservation and Management of Archaeological Sites, 11 (2) 133-47.

(2010) 'Negotiating Authentic Objects and Authentic Selves: Beyond the Deconstruction of Authenticity', Journal of Material Culture, 15 (2) 181-203.

Jones, S., Jeffrey, S., Maxwell, M., Hale, A. and Jones, C. (2017) '3D Heritage Visualisation and the Negotiation of Authenticity: The ACCORD Project', International Journal of Heritage Studies 24 (4) 333-53.

Jones, S. and Yarrow, T.G. (2013) 'Crafting Authenticity: An Ethnography of Conservation Practice', Journal of Material Culture 18 (1) 3-26.

Kincaid, S. (2020) 'After the Fire: Reconstruction following Destructive Fire in Historic Buildings', The Historic Environment: Policy and Practice, 11 (1) 21-39. DOI: 10.1080/17567505.2019.1681647.

Latour, B. and Lowe, A. (2011) 'The Migration of the Aura, or How to Explore the Original through its Facsimiles', in Thomas Bartscherer and Roderick Coover (eds) Switching Codes: Thinking Through Digital Technology in the Humanities and the Arts, 275-98, Chicago: University of Chicago Press.

Lowe, A., Mitchell, E., Béliard, N., Fornaciari, G., Tomassini, T., Nieto, B. and Damone, G. (eds) (2020) The Aura in the Age of Digital Materiality: Rethinking Preservation in the Shadow of an Uncertain Future, Bologna: Silvana Editoriale/Factum Foundation. www.factum-arte.com/resources/files/ff/publications PDF/the aura in the age of_digital_materiality_factum_foundation_2020_web.pdf.

McDonald, S. (2009) 'Reassembling Nuremberg, Reassembling Heritage', Journal of Cultural Economy, 2 (1-2) 117-34. DOI:10.1080/17530350903064121.

Martin, J. (1991) Rapid Application Development, Toronto: Macmillan. ISBN 0-02-3767758.

Noble, S. (2019) 'Fingal's Cave: The Integration of Real-Time Auralisation and 3D Models', VIEW: Journal of European Television History and Culture, 7 (14) 5-23. ISSN 22130969.

Pink, S., and Morgan, J. (2013) Short-Term Ethnography: Intense Routes to Knowing', Symbolic Interaction, 36 (3) 351-61. DOI:10.1002/SYMB.66.

Ponchio, F., Callieri, M., Dellepiane, M. and Scopigno, R. (2020) 'Effective Annotations Over 3D Models', Computer Graphics Forum, 39 89-105. https://doi.org/10.1111/ cgf.13664.

Pujol, L. and Champion, E. (2012) 'Evaluating Presence in Cultural Heritage Projects', International Journal of Heritage Studies, 18 (1) 83-102.

Stevens, T. (2019) 'The Plaster Cast Collection of the Glasgow School of Art: History, Aura and Experience', Journal of the Scottish Society for Art History, 23 (2018-19) Art Organisations and Institutions in Scotland 23 23-30. ISSN 1362-248X.

Wilson, L., Rawlinson, A., Frost, A. and Hepher, J. (2018) '3D Digital Documentation for Disaster Management in Historic Buildings: Applications Following Fire Damage at the Mackintosh Building. The Glasgow School of Art', Journal of Cultural Heritage, 31 (2018) 24-32. ISSN 1296-2074, DOI:10.1016/j.culher.2017.11.012. 


\section{Authors}

Dr Stuart Jeffrey, https://orcid.org/0000-0003-2084-4174

s.jeffrey@gsa.ac.uk

Prof Steve Love s.love@gsa.ac.uk

Dr Matthieu Poyade https://orcid.org/0000-0002-7229-949X

m.poyade@gsa.ac.uk

All authors: School of Simulation and Visualisation, Glasgow School of Art, 167 Renfrew St. Glasgow.

Corresponding author email: s.jeffrey@gsa.ac.uk 